\title{
MULTIPLE VOICES IN BILINGUAL HIGHER EDUCATION: LANGUAGE CHOICES OF AFRIKAANS/ENGLISH BILINGUALS AT STELLENBOSCH UNIVERSITY.
}

\author{
Marcelyn Oostendorp \\ Stellenbosch University \\ Christine Anthonissen \\ Stellenbosch University
}

\begin{abstract}
This paper uses a sociocultural theory and heteroglossic approach to investigate the bilingual learning experience of seven Afrikaans/English bilinguals at Stellenbosch University. In particular these bilinguals were asked to reflect on the language choices they make when completing various assessment tasks and when they are internalising new information. These students were also asked to reflect on the ways in which a bilingual learning context has changed their language proficiency. It is evident from the data that the language choices are made for a multiplicity of reasons, and that the participants draw on a number of different voices, some contradictory, to articulate their experience. These findings are discussed especially in connection to the implications for policy makers, showing that methodologies such as surveys and questionnaires in which participants are requested to make a choice, do not reflect the heteroglossic and ambiguous nature of bilingualism.
\end{abstract}

\section{INTRODUCTION}

Higher education worldwide has become increasingly bilingual in the last 20 to 30 years. A variety of reasons account for such an increase in institutionalised bilingual higher education, which include the widespread use of English in academia internationally, student exchanges across national boundaries, and increasingly diverse student populations that oblige the use of a lingua franca or bilingual modes of teaching and learning. According to Purser (2000: 451) a bilingual university is a product of not only the linguistic context in which it exists, but also the political and social conditions of the time during which the institution was founded. Some universities such as Åbo Akademi in Finland and the University of Ottawa in Canada have been in existence for more than a century in the bilingual communities they serve. Other bilingual universities such as the Free University of Bozen in Italy and the European University Viadrina were established as recently as the 1990s (Purser, 2000: 452). In European and Canadian contexts bilingual universities were established either to accommodate minorities, or to include English as a medium of teaching and learning in countries where it is not a majority language (Anckar, 2000; Beillard, 2000; Maldonado, 2000).

In South Africa, with its policy of 11 official languages, only two (Afrikaans and English) are used as media of instruction (MoI) at tertiary education level. This is true even of universities such as the University of Venda in Limpopo province or Fort Hare in the Eastern Cape, where the majority of the students are L1 speakers of other South African languages. Following the options 
students have in secondary education, the default language of higher education countrywide is English. The five higher education institutions which used Afrikaans-only as medium of instruction, ${ }^{1}$ and so catered for predominantly white Afrikaans first language (L1) students during the apartheid era, were compelled to transform after 1994 to accommodate a more diverse and multilingual student population. This drive towards transformation necessarily brought conflict with Afrikaans-only language policies (Van der Walt, 2004). Consequently, there has been a steady shift from an Afrikaans-only policy to policies that integrate or validate various degrees of multilingualism. Although there is much lip service to the full range of 11 official languages, the reference to multilingualism in tertiary institutions refers mainly to the choice (or opposition) between Afrikaans and English in an increasingly English-dominant environment. To maintain Afrikaans and simultaneously give access to English, various strategies have been implemented. The Potchefstroom campus of North-West University (NWU) opted to use simultaneous interpreting where lectures are presented in Afrikaans; the University of the Free State (UFS) and University of Pretoria (UP) introduced parallel teaching of the same material in separate Afrikaans and English groups; The Randse Afrikaanse Universiteit, which started out as an Afrikaans MoI university in 1967, remodelled itself in 2004 as the University of Johannesburg (UJ) with a language policy introduced in 2006 which stated that it "promotes multilingualism and designates Sesotho sa Leboa, English, IsiZulu and Afrikaans as its primary languages for academic, administrative, communication and marketing purposes'. It has in the meantime, on pragmatic grounds, accepted English as the only MoI. Stellenbosch University (SU), the oldest Afrikaans university in the country, currently allows for a larger variety of bilingual teaching models. Even so, nowhere is language policy a more contested issue than at SU. This university has shifted from an Afrikaans-only to a bilingual Afrikaans/English language-in-education policy, although Afrikaans is still considered the dominant language. Student and staff reactions to the university's language policy, as well as classroom practices in bilingual lectures, have been investigated (Leibowitz, 2006; Schlemmer, 2008; Van Heusden \& Lambrechts, 2008; Brewis, 2013). However, there is less research on the effects of the policy on the learning of students and on the use of language in constructing knowledge. Also less investigated, are the ways in which students develop their language proficiencies and construct their linguistic identities.

This paper reports on one aspect of a larger project (see Oostendorp, 2012) that investigated the effects of increased exposure to two languages on academic literacy, on academic achievement and on the language choices that students made in relation to learning. The paper will report on the latter, focusing on students' reflection on languages used in assessment and in internalising new knowledge. It will also reflect on the reasons they offer for these selections. We will report on the responses of seven students registered in the Faculty of Science who were interviewed in their second and third years of study. The student responses will be analysed by using Bakhtin's (1981) notions of multi-voicedness and heteroglossia. The study points to the tension between centripetal and centrifugal forces (Bakhtin, 1981), thus between a drive to stasis and stability as opposed to a drive towards movement and change in managing the complexities of multilingual contexts. This will be discussed in relation to language policy in higher education in South Africa.

\section{LANGUAGE-IN-EDUCATION POLICY AT STELLENBOSCH UNIVERSITY}

As academic home to many political and business leaders since unification in 1910, SU is often associated with Afrikaner nationalism. Until recently, due to the same apartheid legacy as the other longer-established universities, student enrolment was overwhelmingly white; and thus 
under-representative of the ethnic and linguistic diversity of the country. Enrolment of students with languages other than Afrikaans as L1 has significantly increased over the past 15 to 20 years. However, this has only limitedly changed the diversity profile of enrolment. Also, according to policy, academic staff appointments are made with a view to the scholarly excellence of candidates, so that increasing numbers of the lecturing staff are L1 speakers of languages other than Afrikaans. This, together with a preference and demand to publish academic work in English, has led to this historically Afrikaans university increasingly moving towards bilingual language policies and practices. Considering impressions that countrywide the continued use of Afrikaans in public spaces is steadily diminishing, the past 10 years has seen the development at SU of much controversy ${ }^{2}$ around how Afrikaans is to be maintained as a medium of education at this institution. From time to time the debate on the SU language policy flares up, seeking to resolve questions as to maintenance of Afrikaans as the only language of teaching (at least at undergraduate level), or of introducing more English as medium of education. Introduction of English is not only a pragmatic consideration related to the L1s of students and teachers; many also see this as a means of including a larger and more representative part of the country's population. Brink (2006: 81) states that there are both soft recommendations that 'Stellenbosch should have and exercise a commitment to Afrikaans' and harder demands that 'Stellenbosch should have the non-negotiable and sharply-delineated identity of an Afrikaans university'. Arguments for and against the sustained use of Afrikaans as MoI at SU abound.

The current language policy of SU starts by saying that it 'is committed to the use and sustained development of Afrikaans as an academic language and accepts the responsibility to promote it' (Stellenbosch University, 2002). Afrikaans is the default language of teaching and learning at undergraduate level, with English being used to a greater extent at the postgraduate level. The policy also states that steps are being taken to promote isiXhosa as an emerging academic language. Although Afrikaans is regarded as the default language of instruction at the undergraduate level, various options for $\mathrm{MoI}$ are offered through the policy for different circumstances. The language proficiencies of the lecturer, the composition of the student groups in different modules and the nature of a particular programme are all taken into consideration. The options are to offer particular modules in Afrikaans only (the A-option), in English only (the E-option), using both languages (the T-option), ${ }^{3}$ and in both English and Afrikaans in separate, parallel sessions (the A/E-option). The A/E-option is a model used more systematically at other historically Afrikaans universities (UP and UFS), but there have been strong initiatives to institute the parallel-medium option more systematically at SU. Since 2012, where the timetable or class size prohibits division into two groups for each of the two MoIs, an increasing number of modules are offered in one language, with simultaneous translation facilities provided in the other. The latest revisions to the policy (Stellenbosch University, 2007) recommend the acceptance of the A/E specification as 'a viable option, which, where it is academically attainable and accountable, and affordable, is to be encouraged'.

According to the official language policy, the A-option offers lectures in Afrikaans, study material may be in Afrikaans and/or English, while the course framework may be given in Afrikaans and English to accommodate students with English L1 or an English MoI background. The T-option offers lectures in which Afrikaans as well as English is used interchangeably, ${ }^{4}$ though with a provision that use of Afrikaans may not be reduced to less than $50 \%$. Textbooks and reading materials are in Afrikaans and/or English, while other teaching materials are in Afrikaans and English. The E-option is exceptional at undergraduate level. This option offers lectures primarily in English, textbooks and reading matter may be in Afrikaans and/or English, notes are in English (where required core notes may be provided in Afrikaans), with other teaching and learning materials in English. In the University calendar the language option of each 
module has to be specified (which gives students prior notice as to which languages will be used in which mode of teaching). In registering the language options, those departments who elect the T- or E-option, have to put forward acceptable motivation for this particular choice. Such motivations typically include references to the L1s of participants, as well as to programmes uniquely presented at SU, so that students who wish to follow them have no choice but to register at this institution.

The language policy of SU thus integrates multilingual learning options in various different ways across faculties and departments. What is clear is that English features in all of these options, which presupposes that students entering Stellenbosch University all require a fair level of English proficiency to function effectively in their academic work. We shall report on the effects of these options as the students themselves have articulated them.

\section{THEORETICAL FRAMEWORK}

This paper has been informed by a framework that draws on the bilingual voice in research (Pavlenko, 2005, 2006), meaning that bilinguals themselves inform the researcher directly about the bilingual experience. Pavlenko (2005) has indicated that bilingual voices have been largely absent in bilingualism studies. Integrating such voices does not assume the accounts of bilinguals to present absolute truths or the final word; it does acknowledge the constructed nature of these accounts. However, such an approach values the contribution of these voices for being just as informative as language testing or experimental research. This approach has provided valuable information on emotional aspects of bilingual living, on how each language features in bilingual experiences, as well as on the struggle, desire, anxiety and resistance to be accepted in both language communities where there may be limited overlap (Pavlenko, 2005, 2006; Kramsch, 2010). The approach has also pointed to the multiplicity of the bilingual experience, and has shown that language choices are made not only on the basis of a speaker's proficiency levels, but often as a means of exercising voice and agency (Norton, 1997; Kramsch, 2010). The increased focus on the bilingual voice for gaining new insights has developed alongside increased use of sociocultural approaches in second language acquisition (SLA) and bilingualism studies. These approaches, which favour speaking to bilinguals themselves and not only about them, have partly been the result of increased accessibility of the work of Vygotsky (1978) and Bakhtin (1981). Vygotsky's (1978) sociocultural theory has afforded social activity a central place in studies on language development. According to the sociocultural research tradition, social activity 'precedes the emergence of individual forms of consciousness' (Kramsch, 2000: 133). Thus, Kramsch (2000) finds that linguistic signs or psycholinguistic processes are not shaped primarily by physical context; rather, they are created through social activity.

Bakhtin (whose initial aim was to introduce new ways of interpreting literature) put forward two concepts, namely heteroglossia and multi-voicedness. Bakhtin (1981) used heteroglossia to refer to the multiple genres and registers used in language, and multi-voicedness to refer to the fact that every utterance is always produced in response to previously uttered speech, thus every utterance is made up of a variety of different voices. Other concepts in Bakhtin's (1981) work that will be used here are those of centripetal and centrifugal forces and the tension between the two. Centripetal forces are described by Bakhtin (1981) as those which strive towards unified or standard languages, and which are always in conflict with centrifugal forces which strive towards acknowledging and incorporating the heteroglossia prevalent in society. 
The notion of 'heteroglossia' has been used in studies on literacy, bilingual education and teaching English as a second language (Corson, 2001; Lilis, 2003; Lea \& Street, 2006; Busch, 2010) to explain how different styles, registers, languages and language varieties articulate different kinds of experiences. Busch and Schick (2006: 216) point out that most classrooms are inherently heteroglossic; even those that at first sight might look monolingual. They advise that 'overcoming the monolingual habitus in education is decisive when it comes to questions of school success or failure, of social inclusion or exclusion' (Busch \& Schick, 2006: 230). The heteroglossic practices used by students in learning contexts have also been referred to as 'translanguaging'. This concept, originally coined in the context of Welsh bilingual education pedagogy, referred to the reception of information 'through the medium of one language (e.g. English)' and the use of this information through the other language (e.g. Welsh)' (Lewis, Jones $\&$ Baker, 2012). The meaning of the concept has, however, been extended to describe and explain bilingual communication practices outside of the classroom (Lewis et al., 2012). This concept is closely related to the notion of 'heteroglossia' and fits in with a sociocultural approach to teaching and learning (Lewis et al., 2012: 645). This article will show how the bilingual voice assists in gauging the experiences of bilinguals in a context which is characterised by heteroglossia in various domains. The discourses of the students will be analysed with particular attention to how multiple voices feature in their discourse and with the goal to make recommendations on the practical implications of concepts such as 'heteroglossia' and 'translanguaging' for language policy and planning in higher education.

\section{METHOD}

The participants in this study are students who were selected from a larger sample that was targeted in an investigation of academic literacy development. ${ }^{5}$ All of the 87 participating students were approached to take part in semi-structured interviews in which questions were directed at the nature of their bilingual learning environment, the effects of this environment on their language proficiency, and the language choices they make in day-to-day bilingual learning (see interview schedule in Addendum). Only seven students elected to take part in these interviews. As the goal of the interviews was not to make generalisable assumptions, but to investigate the individual variability in the bilingual learning experience and to gain insight into bilingual living from bilinguals themselves, the small number of participants was not perceived as a problem. The participants were Jaco $^{6}$ (male, 19 years old), Juanita, Rikki, and Elisna (all female, 19 years old) and Byron, Gregg and Elton (all male, between 20 and 22 years old). The first four were all in their second year of study, and the other three in their third year during the time of data collection in 2010. All these students had attended monolingual Afrikaans schools or had been in the Afrikaans stream of a parallel-medium Afrikaans/English school. All the students had taken English either as first additional language or as home language ${ }^{7}$ up to their final school year, i.e. for at least 10 school years. These participants were therefore more than minimally bilingual and testified to considerable exposure to uses of English outside of the classroom. Nevertheless, in teaching and learning at university they were confronted with much more English-in-education than they had previously experienced.

The data obtained from the interviews were subjected to an initial thematic analysis, according to the method of Miles and Huberman (1984). The notes of each interview were consulted on more than one occasion at different points in time, and were re-ordered and organised a number of times, until the final categorisation was decided upon. The questions of the interview were used as tool of categorisation, although themes were also included that were not necessarily directly 
introduced in the questions, but were based on information volunteered by participants. This formed only the first part of the analysis. Bearing in mind the criticism against thematic analysis that it often proceeds without any particular theoretical framework (see e.g. Pavlenko, 2007) the initial thematic analysis was supplemented by an analysis grounded in sociocultural theory with a particular interest in social activity and agency (see Kramsch, 2000 and Lantolf, 2000, 2006). In the second part of the analysis the concepts of heteroglossia and multi-voicedness (Bakhtin, 1981) were used to interpret the data. These theoretical constructs allowed us to investigate how the participants draw on outside and prior discourses to construct their experiences, and to relate their perceptions of their language abilities, language use and language choice in different domains. These concepts also allowed for an approach that would highlight how the social activities in which these participants were engaged, shaped their knowledge and use of language.

\section{ANALYSIS}

The analysis to be presented here, as mentioned in section 1 above, is ordered around the themes that arose from the interviews with Afrikaans L1 students in bilingual higher education. These interviews were constructed in relation to the research questions of the project, thus to questions as to how learners relate to the new experience of using two languages in higher education. The following themes will be addressed: languages used in construction of knowledge, language choice for participation in learning as social activity, languages used in exhibiting and applying knowledge (i.e. in assessment), heteroglossia and multi-voicedness in student responses, and finally, the tensions between centripetal and centrifugal forces exhibited in this discourse.

\subsection{LANGUAGES USED IN CONSTRUCTION OF KNOWLEDGE}

Vygotsky (1978: 34) made the point that learners construct knowledge from what is presented to them, rather than just reproducing it. His conceptualisation of 'learning' is one that sees activities such as memorising, repetition and paraphrase as actions that may facilitate, but do not themselves constitute, students' construction of knowledge. Questions 5 to 8 in the interview schedule (see Addendum A) address the matter of using language in constructing knowledge. Specifically, our interest was in (i) which languages students use in processing new information, (ii) whether one language served students better than another in all knowledge construction, or in some areas of knowledge construction rather than others, (iii) whether introducing English as an MoI has had a noticeable effect on students' processes of knowledge construction in specific subjects, and (iv) whether students noticed any wider cognitive advantages or disadvantages in the new experience of using two languages in learning.

In the interviews all the students reported that they use both Afrikaans and English in processing new information and developing their understanding of academic concepts, ideas and arguments. Some, such as Jaco, believed that they understand concepts and follow arguments equally well in Afrikaans and English, while others, such as Elisna, reported that they understand some concepts better in English and others better in Afrikaans. Elisna stressed the importance of the larger context in which she finds herself, i.e. for her the subject and lecturer involved and how the work is presented, makes a difference. Overall, students reported Afrikaans as the preferred (although not exclusive) language for making sense of new information. Gregg said that he understands concepts better in Afrikaans, although he sometimes uses English to facilitate understanding. Byron, although he reported a preference for Afrikaans in trying to understand new information, believed that he understands learning material (and spoken input) equally well in both languages. 
All the responses indicated that the students did not perceive learning through medium of English to have a negative effect on their academic performance; however, they conceded that studying through medium of English took more time than when they used Afrikaans only. Nevertheless, learning through the medium of both languages was also perceived to facilitate understanding. Byron articulated his experiences in learning through medium of English in the following way:

1. Aan die begin was die aanpassing om deur Engels te leer moeilik. Dit het al hoe makliker geraak en nou selfs verkies ek dat Afrikaans en Engels in dieselfde klas gebruik word. Afrikaans help met die verstaan van die werk, terwyl meeste van die informasie in Engels is.

['In the beginning I found the adjustment to learning through English difficult. It gradually became easier and now I actually prefer that Afrikaans and English be used in the same class. Afrikaans helps with understanding of the work, while most of the information is in English.']

Elton summarised his similar experiences slightly differently:

2. Dis moeiliker, want die werkslading is meer, maar dis ook makliker, want ek verstaan beter as ek deur altwee tale leer.

['It is more difficult because the workload is heavier, but it is also easier because I understand better when I study through both languages.']

All participants view their bilingualism as mainly a positive phenomenon. They seem to believe that understanding and internalising of knowledge is aided by using two languages instead of one.

\subsection{THE ROLE OF LANGUAGE IN LEARNING: CHOICES, AGENCY AND TRANSGRESSION}

In this paper, 'learning' is defined as more than just a cognitive process of assimilating new knowledge. Following the sociocultural tradition, the definition of Lave (1991: 64) is used, according to which learning is 'a social phenomenon constituted in the experienced, lived-in world, through legitimate peripheral participation in on-going social practice'. This definition sees the learning process as a changing, knowledgeable skill which is 'subsumed in processes of changing identity in and through membership in a community of practitioners'. Then mastery of the new skill is 'an organizational, relational characteristic of communities of practice' (Lave, 1991: 64). Kramsch (2000: 133) views the role of language in social activity as purposeful for the action in which it is used. The discussion (and examples) in this section will be based on interview responses that in particularly salient ways reflect the purposefulness of the use of language in learning contexts.

Mostly, participants did not articulate lectures marked by the use of two languages as circumstances in which they had to make choices. The alternation between two languages was justified by two kinds of arguments. First, it is not contested that the bulk of the prescribed work, of all scholarly publication in fact, is in English. None of the participants expected translations of published work to be provided. Second, it is taken as common cause that the student population is made up of Afrikaans L1 as well as English L1 speakers, and that in one way or another, both groups have a right to be accommodated. Linked to this is acceptance of the fact that some lecturers are L1 speakers of English and others L1 speakers of Afrikaans, and that in academic 
work, many prefer to use one rather than the other. Thus, even when students remarked that more Afrikaans (or more English) would have been nice, none expected the particular lecturing context unconditionally to favour the choice of one language over another (see also excerpts 5 to 7 below). The comments of the participants were directed more towards how they manage the use of two languages in lectures and in their own learning. Also, they commented on what directed their own choice of using either Afrikaans or English in writing assignments and other kinds of written assessment.

The data showed that language choice was at times used for exercising agency. According to Van Lier (2008: 162), agency is both an individual trait and a particular way of being in the world. Agency is also seen as 'the ability to control one's behaviour, to engage in behaviour which affects other entities and the self and to produce actions which can be evaluated'. For Van Lier, agency can be related to issues such as 'volition, intentionality, initiative, intrinsic motivation and autonomy'. Examples of this can, for example, be found in the interview conducted with Elisna. She recounted one particular incident where she elected to do assignments in English even though the lecturer conducted the module in Afrikaans simply because she did not like the lecturer or his lecturing style. Elisna's resistance to poor lecturing that prompted her choice to do assignments in English is a conscious use of her L2 as a form of agency. Another example of the exercise of agency, not through language, but about language, is found in Juanita's discussion of her deteriorating English proficiency that she believes is a result of being in the Afrikaans-dominant environment of SU. In her own words:

\section{Ons bure was Engels, my beste vriendin was Engels. Ek het altyd Afrikaanse en Engelse vriende gehad.}

['Our neighbours were English, my best friend was English. I always had Afrikaans and English friends.']

She does not, however, construct herself as a victim of more or less language contact, but as agentive, as in (4):

4. Ek het gekies om na 'n Afrikaanse universiteit toe te kom. My tweede keuse was Vrystaatste Universiteit, nog 'n Afrikaanse universiteit.

['I chose to come to an Afrikaans university. My second choice was the University of the Free State, another Afrikaans university.']

Regarding the position of Afrikaans in the public sphere, three of the participants referred to the prevalence of English in terms that articulate a lack of agency. In the academic environment they report an inability to exercise any control. Jaco expresses it in the following way:

5. Afrikaanssprekendes weet dat hulle in 'n Engelse wêreld leef.

['Speakers of Afrikaans know that they are living in an English world.']

Rikki relates to popular rhetoric which evaluates code-mixing negatively, as in (6):

6. Ek voel dat my Afrikaans ietwat negatief verander het. Dit is jammer dat ek meer my tale meng en dat Afrikaans effens onderdruk word, maar ons moet Engels ook kan gebruik. 
['I feel that my Afrikaans has changed slightly negatively. It is a pity that I mix my languages more and that Afrikaans is somewhat oppressed, but we do have to be able to use English as well.']

Gregg expresses lack of agency in terms of loss, as in (7):

7. Afrikaans raak verlore in al die Engels.

['Afrikaans gets lost in all the English.']

Such characterisations of the position of Afrikaans do voice an impression some have that they should 'do more' in maintaining Afrikaans, but that they do not have the power to change the linguistic dispensation. At the same time, participants admitted that they do develop new strategies in using the two languages they know to negotiate their own positioning and development in the learning context.

One interesting example of exercising agency may be of slightly dubious nature, in that students motivate their choice for using Afrikaans in written assessments by acknowledging how it allows them to frustrate "Turnitin", a standardly-used plagiarism detection tool. Jaco and Byron specifically mentioned that they could directly translate English sources into Afrikaans, and so put very little intellectual effort into their writing. Van der Walt \& Dornbrack (2011) have reported on similar uses of this particular strategy which entails purposeful selection of Afrikaans to avoid the constraints enforced by availability of an instrument which detects the copying of large sections from English texts. In spite of the academically improper motives of which students are clearly aware, the use of multilingual resources in this way can make an interesting contribution to the debate on the boundaries between helpful, justified practices of citation and transgressive ones (see Chandrasoma, Thompson and Pennycook, 2004; Moody, 2007). Limited English competence has often been put forward as motivation for excessive citation; however, using multilingual resources creatively to avoid what amounts to plagiarism has not been investigated. That students refer to the inability of an electronic instrument to recognise word-forword translation into Afrikaans as it would have recognised the original English, confirms their awareness of what is defined as 'plagiarism'. Nevertheless, using language in this way is likely to oblige a kind of intellectual engagement which could contribute to learning, so that translation of English sources into properly equivalent Afrikaans can under given circumstances become a useful strategy in knowledge construction.

\subsection{LANGUAGES USED IN EXHIBITING AND APPLYING KNOWLEDGE (I.E. IN ASSESSMENT)}

The idea of assessment is in essence one of giving students the opportunity to show how they have used spoken and written academic input in constructing their own knowledge of a certain scientific field. So again, considering ideas propagated by Vygotksy (1978: 29), we consider his position that language plays a central role in cognitive development. What emerged in relation to the question about the language in which students complete assessment (see question 2, section 2 in interview schedule) was that all the students testify to using both languages for assessment, although this does not necessarily mean an equal division of time and effort between the two languages.

Various reasons were offered for various selections. For example, Gregg, Jaco and Byron reported that they mostly used Afrikaans to write their assignments. Their own language 
proficiency played an important role in this selection; however, this is not the only reason for their selection of Afrikaans. Another reason that was offered by both Jaco and Byron referred to the fact that writing in Afrikaans allowed them to frustrate the electronic plagiarism detection tool used by the university by translating English sources directly into Afrikaans (see section 5.2 above for more on this aspect).

Predictably, participants mentioned that the specific nature of the modules and how they are taught and tested, influenced the choices they made. Elton stated that his preferred language is Afrikaans; nevertheless, he reported that he did all his assignments for one module in English because he attended the English classes for this module. Elisna reported similarly that she selected the language in which to do assignments depending on the situational context of the module as well as the lecturer concerned (also see section 5.2 above). All the students admitted that they needed a fair level of proficiency in English in order to do well at university, due to the prevalence of English textbooks. In fact, a statement we came across in all the students' interviews was:

\section{Al die handboeke is in Engels.}

['All the textbooks are in English.']

Not only are all the textbooks in English; most of the academic information necessary to complete high-quality assignments is also in English.

Byron summed this up particularly succinctly when he said:

9. Indien jy'n goeie taak wil ingee moet jy Engelse bronne in die hande kry. Daar is min navorsing in Afrikaans en dan moet jy vertaal van Engels na Afrikaans.

['If you want to hand in a good assignment, you have to find English sources. There is not much research in Afrikaans and then you have to translate from English to Afrikaans.']

Thus, in summary, the language choices made by the participants seemed to be in response to proficiency levels, the specific situational context, and utilitarian needs (frustrating the plagiarism detection tool, finding more information). However, such choices also revealed the exercise of agency and voice.

\subsection{HETEROGLOSSIA AND MULTI-VOICEDNESS IN STUDENT RESPONSES}

The contributions of students which articulated agency in language choice were often multivoiced. It is particularly evident when students refer to larger societal discourses both on Anglicisation ("verengelsing") as in (5) above, and on English as a world and universal language as in (7) above.

Jaco's utterance in (5) exhibits an assumption that there is a collective Afrikaans voice that acknowledges English as a pervasive voice even within the Afrikaans world. The dialogic nature of the participants' discourses is emphasised by the fact that the same ones who complain about the Anglicisation of South African society and large parts of the world, also attest positively to the unifying qualities of English. For example, Gregg, who mentions that in the T-option lectures English takes preference to the extent that Afrikaans 'gets lost' (see (7)), later refers to the 
inclusive properties of English; saying that English facilitates conversation, as in (10) where he was referring particularly to bridging cultural and linguistic differences.

10. Engels maak kommunikasie makliker, soos gespreksvoering...

['English makes communication easier, as in conversation...']

The interviews highlighted that students draw not only on outside voices, i.e. on discourses and rhetoric of other contexts and other speakers, but also on voices belonging to former selves and imagined selves. According to Kramsch (2010: 99), testimonies from bilingual users themselves 'reveal such phenomena as: heightened perceptions and emotions, imagined identities, projected selves, idealizations or stereotypes of the other, awareness of one's body, feelings of loss or enhanced power.' Our data illustrate some of these, such as when Byron (in (1), repeated as (11) below) relates the process of adjusting to the use of two languages in lectures, the English material and the supportive role of Afrikaans in his learning and developing new knowledge.

11. Aan die begin was die aanpassing om deur Engels te leer moeilik, dit het al hoe makliker geraak en nou selfs verkies ek dat Afrikaans en Engels in dieselfde klas gebruik word. Afrikaans help met die verstaan van die werk, terwyl meeste van die informasie in Engels is. (= (1) above)

['In the beginning I found the adjustment to learning through English difficult. It gradually became easier and now I actually prefer that Afrikaans and English be used in the same class. Afrikaans helps with understanding of the work, while most of the information is in English.']

This portrayal of himself as initially finding the increased use of English in a learning context a challenge, but one that he gradually overcame, draws on previous discourses about language in education and his own position within the discourse. In (11), Byron externalises an internal dialogue, referring to an earlier self but also an imagined self, a self who can use both languages in a helpful way. This illustrates what Kramsch (2005: 11) calls information about 'remembering how' and 'imagining what if'. This excerpt shows how the bilingual voice, the contribution of the bilingual speaker him-/herself, gives information that would otherwise not be accessible.

\subsection{TENSION BETWEEN CENTRIFUGAL AND CENTRIPETAL FORCES}

The language choices of the participants reflect how speakers negotiate and integrate the knowledge and use of two languages, in this case Afrikaans and English. The tension between monoglossic forces that expect adherence to monolingual standards and the heteroglossic realities of students at a bilingual university in a multilingual country are evident in the discourse. Such tension between centrifugal and centripetal forces (see section 3 above, Bakhtin, 1981) is even more evident when students discuss the effects of using both languages and their awareness of increased code-switching. Participants in this study shape their discourses about how they use two languages with a monolingual perspective - what Heller (1999) refers to as "parallel monolingualism'. Thus, they subscribe to a popular and widely held normative view of bilingualism as the knowledge and use of distinct language systems that operate separately and should not be activated simultaneously. This is illustrated in (6) above (section 5.2) where Rikki refers to increased code-switching as a deplorable practice. 
Juanita's reference to her loss of English language proficiency due to a predominantly Afrikaans environment at university also illustrates such a monolingual ideology of language. For these participants, interchangeable use of two languages and a perceived loss of proficiency in either English or Afrikaans are negative developments caused by the bilingual educational practices. However, even if begrudgingly, practical realities and the necessity and value of a lingua franca such as English, are conceded.

These multi-voiced and heteroglossic responses hold implications for the way in which language policy and planning is to be researched in this and similar higher educational contexts.

\section{IMPLICATIONS FOR LANGUAGE POLICY AND PLANNING}

The students who participated in the study draw on outside voices, aspirations, desires and imaginings of themselves and others when they describe the effects of the language policy and their particular choices, as well as when they justify such choices. The participants' use of their languages is embedded in social activity; their agency in language choice is related to their experiences as students.

In the student responses they refer to prior experiences and to popular perceptions of language and language use; they highlight their own agency, but also their difficulties and feelings of being limited in some cases. It appears that their linguistic resources, their access to two languages in higher education, at times cause ambivalence and uncertainty. The participants largely adhere to monoglossic ideologies of language use. However, students also attest to using the two languages they know in various ways that allow them to exercise agency, which in some cases include subversive or transgressive uses of language.

The student responses further reveal the co-constructed nature of their discourses. The shaping role of context (both immediate and larger societal context) is illustrated in that students report on outside pressures which limit (even inhibit) their use of Afrikaans. These issues are not isolated from the very public language policy debate at SU, among alumni countrywide and in the local media. The perception, held by many who belong to other language communities in South Africa, of L1 speakers of Afrikaans perpetuating the legacy of apartheid, is not easily overcome. The students who took part in this study expressed feelings of being threatened, at least to some extent, by the increased use of English, also in attributing what they see as their 'deteriorating' proficiency of Afrikaans to the increased exposure to English. However, the very same students who feel that Afrikaans is losing ground to English also admit the usefulness of English for social and academic purposes. This multi-voicedness in student accounts has important implications for research on language policy, planning and implementation. Often the views of students or other stakeholders toward policies and implementation are ascertained by means of surveys that give a set of predetermined options/choices (Marley, 2004; Leibowitz, 2006; Palozzi, 2006). The results of such surveys are then presented in graph or table format providing statistics about preferences and attitudes. Although such research surveys are a useful starting point for determining trends and attitudes, such a methodology is not sensitive to the heteroglossia multilingual students at a multilingual university display. The very research methods used to investigate phenomena and processes can thus give in to centripetal forces which do exactly the opposite of what is intended. Instead of giving a representation of how students or other individuals experience aspects of language policy and its implementation, the research method can confine their experiences to a number of pre-selected options. Participants are then forced to articulate their experience in pre- 
defined categories leaving little room for ambiguity or multi-voicedness. Such an approach to the topic strips the multilingual experience of some of its defining characteristics.

Pavlenko and Lantolf (2000: 155) point out that individuals have 'intentions, agency, affect and above all histories'. Ticking a box or indicating competence in terms of a Likert scale rarely enables researchers to understand the histories, dilemmas, choices and intentions of individuals. Increasingly there are calls that language policy and planning research should engage with ethnographic approaches and should focus more on personal spaces and the everyday encounter to inform policy making (Shohamy, 2006; Williams \& Stroud, 2013). Language planners need to take note of the complex ways in which bilinguals report on using language, and then make sure that multilingual policies mirror the findings of these approaches. Rather than forcing bilingual educational practices to fit a monoglossic point of view, or monolingual views of multilingualism, the complexity of multilingual knowledge construction in formal education needs to be recognised and accommodated. Williams and Stroud (2013), following Hinchliffe and Whatmore (2006: 131), argue that policies should be informed less by experts and more by language users at grassroots, thus by those who actually live the multilingual experience. Although pedagogical approaches which use practices such as translanguaging in the classroom have been introduced (see Lewis et al., 2012 for an overview), higher education has been largely lagging behind. Some excellent theoretical suggestions have been made about using such practices in South African higher educational institutions (Stroud \& Kerfoot, 2013). However, no systematic and sustained attempts have been made to develop policies and pedagogies from the perspective of the heteroglossic situation of bilinguals in higher education. This paper has paid attention to some of the heteroglossic practices that bilinguals themselves report. It is evident from the findings that there will always be tension between centripetal and centrifugal forces; such tensions should not be denied but should rather be used to inform us on the best practices in multilingual teaching and learning, and on how to use multilingualism as a valuable resource towards achieving educational goals more effectively.

\section{END NOTES}

\footnotetext{
${ }^{1}$ A sixth university which started out using Afrikaans-only as MoI, the University of the Western Cape (UWC), was established under apartheid regulations specifically to cater for the Afrikaans coloured population of the Western Cape. However, in challenging this system and inviting students from across the racial spectrum in the late 1980s, English had within 10 years become the default $\mathrm{MoI}$ in an increasingly multilingual staff and student community.

${ }^{2}$ For more on the language policy debate see Hugo (1998), Mabokela (2001), Giliomee (2004) and Du Plessis (2006).

${ }^{3}$ The T represents "tweetalig", i.e. the T-option allows for bilingual education - the use of two languages in teaching and learning.

${ }^{4}$ Interchangeable use assumes that students are sufficiently bilingual to understand both languages, so that literal translation and "blind repetition" can be avoided. There appears to be a wide range of formats in which the T-option is presented, including code-switching at regular intervals; giving certain sections in one language with a summary in the other; use of more Afrikaans in the spoken delivery while overheads, PowerPoint presentations and class notes give more English; and so on.

${ }_{6}^{5}$ Ethical and institutional clearance was obtained from the Stellenbosch University Research Office.

${ }^{6}$ To protect privacy, the names used are not the participants' real names.

${ }^{7}$ The term "additional language" is used in reference to the second or third language learners take as school subjects in South Africa. The term "home language" is used in reference to the first language a student brings to school and has as MoI. It is obligatory to take two language subjects in the South African school system, the home language and at least one additional language. In many schools, learners are allowed to take their first additional language on home language level, rather than on second language level. Thus, a learner with Afrikaans as home language can take Afrikaans and English at school, where either Afrikaans and English are both studied on home language level, or where Afrikaans is studied on home language level, and English on second language level (i.e. on "first additional language" level).
} 


\section{REFERENCES}

ANCKAR, O. 2000. University education in a bilingual country: The case of Finland. Higher Education in Europe, XXV(4): 499-506.

BAKHTIN, MM. 1981. The dialogic imagination. Four essays. Holquist, M (ed.), translated Emerson, C \& Holquist, M. Austin: University of Texas Press.

BEILLARD, J. 2000. Bilingualism in a Canadian context: The case of the University of Ottawa. Higher Education in Europe, XXV(4): 469-476.

BRINK, C. 2006. No lesser place. The taaldebat at Stellenbosch. Stellenbosch: Sun Press.

BREWIS, B. 2013. Die bevorderlikheid van opvoedkundige tolking vir effektiewe onderrig en leer binne die konteks van die Fakulteit Regsgeleerdheid aan die Universiteit Stellenbosch. Unpublished MA thesis. Stellenbosch: Stellenbosch University.

BUSCH, B. 2010. School language profiles: valorizing linguistic resources in heteroglossic situations in South Africa. Language and Education, 24(4): 283-294.

BUSCH, B \& J SCHICK. 2006. Educational materials reflecting heteroglossia: Disinventing ethnolinguistic differences in Bosnia-Herzegovina, in S Makoni, \& A Pennycook (eds.). Disinventing and reconstituting languages. Clevedon: Multilingual Matters. 216-232.

CHANDRASOMA, R, C THOMPSON \& A PENNYCOOK. 2004. Beyond plagiarism: Transgressive and nontransgressive intertextuality. Journal of Language, Identity and Education, 3(3): 171-193.

CORSON, D. 2001. Language, diversity and education. Mahwah, New Jersey: Lawrence Erlbaum.

DU PLESSIS, T. 2006. From monolingual to bilingual higher education: The repositioning of historically Afrikaans-medium universities in South Africa. Language Policy, 5: 87-113.

GILIOMEE, H. 2004. The rise and possible demise of Afrikaans as public language. Nationalism and Ethnic Politics, 10: 25-58.

HELLER, M. 1999. Linguistic Minorities and Modernity: A Sociolinguistic Ethnography. London, New York: Continuum.

HINCHLIFFE, S \& S WHATMORE. 2006. Living cities: towards a politics of conviviality. Science as Culture, 15(2): 123-138

HUGO, P. 1998. Transformation: The changing context of academia in post-apartheid South Africa. African Affairs, 97: 5-27.

KRAMSCH, C. 2000. Social discursive constructions of self in L2 learning, in JP Lantolf(ed.). Sociocultural theory and second language learning. Oxford: Oxford University Press. 133154.

KRAMSCH, C. 2005. The multilingual experience: Insights from language memoirs. Transit [Online] 1(1). Available at: http://www.escolarship.org/uc/item/9h79g172

KRAMSCH, C. 2010. The multilingual subject. International Journal of Applied Linguistics, 16(1): 97-110.

LANTOLF, JP. 2000. Introducing sociocultural theory, in JP Lantolf(ed.). Sociocultural theory and second language learning. Oxford: Oxford University Press. 1-26. 
LANTOLF, JP. 2006. Sociocultural theory and L2. State of the Art. SSLA, 28: 67-109.

LAVE, J. 1991. Situating learning in communities of practice, in JL Resnick, J Levine \& S Teasley (eds.). Perspectives on socially shared cognition. Washington DC: American Psychological Association.

LEA, MR \& BV STREET. 2006. The 'academic literacies' model: Theory and applications. Theory into Practice, 45(4): 368-377.

LEIBOWITZ, B. 2006. Survey of the Experience of the Implementation of the Stellenbosch University Language Policy and Plan. Executive summary [Online]. Available: http: //www.sun.ac.za/university/Taal/Hersiening/docs/execsummary of language survey 7 Sept 2006.pdf.

LEWIS, G, B JONES \& C BAKER. 2012. Translanguaging: origins and development from school to street and beyond. Educational Research and Evaluation, 18(7): 641-654.

LILIS, T. 2003. Student writing as 'academic literacies': Drawing on Bakhtin to move from critique to design. Language and Education, 17(3): 192-205.

MABOKELA, RO. 2001. Selective inclusion: Transformation and language policy at the University of Stellenbosch, in RO Mabokela \& KL King (eds.). Apartheid no more: case studies of Southern African universities in the process of transformation. Westport: Greenwood Publishing. 59-72.

MALDONADO, NI. 2000. The teaching of English in Puerto Rico: One hundred years of degrees of bilingualism. Higher Education, XXV(4): 488-497.

MARLEY, D. 2004. Language attitudes in Morocco following recent changes in language policy. Language Policy, 3: 25-46.

MILES, MB \& A HUBERMAN. 1984. Qualitative data analysis. A sourcebook of new methods. London: Sage

MOODY, J. 2007. Plagiarism or intertextuality? Approaches to teaching EFL academic writing. The Asian EFL Journal Quarterly, 9(2): 195-210.

NORTON, B. 1997. Language, identity and the ownership of English. TESOL Quarterly, 31(3): 409-429.

OOSTENDORP, M. 2012. Effects of the second language on the first: Investigating the development of 'conceptual fluency' of bilinguals in a tertiary education context. Unpublished PhD dissertation. Stellenbosch: Stellenbosch University.

PALOZZI, VJ. 2006. Assessing voter attitude toward language policy issues in the United States. Language Policy, 5: 15-39.

PAVLENKO, A. 2005. Emotions and multilingualism. Cambridge: Cambridge University Press.

PAVLENKO, A. 2006. Bilingual minds. Emotional experience, expression and representation. Clevedon: Multilingual Matters.

PAVLENKO, A. 2007. Autobiographic narratives as data in applied linguistics. Applied Linguistics, 28(2): 163-188.

PAVLENKO, A \& JP LANTOLF. 2000. Second language learning as participation and the (re)construction of selves. In Lantolf, JP (Ed), Sociocultural theory and second language learning. Oxford: Oxford University Press. 155-178. 
PURSER, L. 2000. The bilingual university - general reflections on its origins, mission and functioning. Higher Education in Europe, XXV(4): 451-459.

SCHLEMMER, L. 2008. Voorgraadse Studente op die Universiteit van Stellenbosch en die Taalbeleid. 'n Strategiese Meningsopname. Available at: http://www.sun.ac.za/university/Taal/Hersiening/docs/Verslag\%20Raadsondersoek\%20na \%20voorgraadse $\% 20$ studente $\% 20$ en $\% 20$ die $\% 20$ Taalbeleid.pdf.

SHOHAMY, E. 2006. Language policy: hidden agendas and new approaches. New York: Routledge.

STELLENBOSCH UNIVERSITY. 2002. Language policy of Stellenbosch University. Available at: http://www.sun.ac.za/university/Taal/dokumente/LangPolFinal2002.pdf.

STELLENBOSCH UNIVERSITY. 2007. Revision of language policy of the Stellenbosch University. http://www.sun.ac.za/university/Taal/Hersiening/docs/HersieningTaalbeleid_e.pdf

STROUD, C \& C KERFOOT. 2013. Towards rethinking multilingualism and language policy for academic literacies. Linguistics and Education, 24(4): 396-405.

VAN DER WALT, C. 2004. The challenge of multilingualism: in response to the language policy for higher education. SAJHE, 18(1): 140-152.

VAN DER WALT, C \& J DöRNBRACK. 2011. Academic biliteracy in South African higher education: strategies and practices of successful students. Language, Culture and Curriculum, 24(1): 89-104.

VAN HEUSDEN, M \& H LAMBRECHTS. 2008. Doeltreffende onderrig in die veeltalige klaskamer met die fokus op taalgebruik. Available at: http://stbweb02.stb.sun.ac.za/ctl/documents/KLAD 3 VERSLAG DESEMBER 2008.pdf.

VAN LIER, L. 2008. Agency in the classroom, in JP Lantolf \& ME Poehner (eds.). Sociocultural theory and the teaching of second languages. London: Equinox. 163-186.

VYGOTSKY, L. 1978. Interaction between learning and development, in Mind and Society. Cambridge: Harvard University Press. Reprinted in M Gauvain \& M Cole (eds.). 1997. Readings on the Development of Children. New York: W. H. Freeman and Company.

WILLIAMS, QE \& C STROUD. 2013. Multilingualism in transformative spaces: contact and conviviality. Language Policy, 12(4): 289-311. 


\section{Acknowledgements}

We would like to acknowledge the financial contribution of the Andrew Mellon Foundation for funding the larger $\mathrm{PhD}$ project (Effects of the second language on the first) that provided the data for this article.

\section{BIOGRAPHICAL NOTE}

Marcelyn Oostendorp is a lecturer in the Department of General Linguistics, Stellenbosch University. Her research interests include multilingualism in various institutional and informal settings as well as multimodal forms of meaning-making.

Email: $\underline{\text { moostendorp@sun.ac.za }}$

Christine Anthonissen is an associate professor in the Department of General Linguistics, Stellenbosch University. Her research focuses on typical South African discourses such as ones of censorship during the 1980 s, public hearings on histories of violence in the 1990s and HIV-treatment since 2003. Currently she is investigating sociolinguistic aspects of bilingualism and multilingualism in a context where policy and practice do not suitably meet.

Email: ca5@sun.ac.za 


\section{ADDENDUM A: INTERVIEW SCHEDULE}

Interview questions relating to current language use in academic setting

\section{Afrikaans}

1. Vir watter van jou eerstejaarmodules het jy lesings bygewoon wat in die T- of E-opsie aangebied word?

2. In watter taal/tale skryf jy jou werkopdragte en toetse of eksamens?

3. Voel jy dat jou Engels verbeter het sedert jy universiteit toe gekom het? Indien ja, waaraan sou jy die verbetering toeskryf? Indien nee, sou jy daarop wou uitbrei?

4. Voel jy dat jou eerstetaal (Afrikaans) op enige manier verander het sedert jy universiteit toe gekom het? Gee asseblief 'n bietjie toeligting.

5. Indien ja, dink jy dat die verandering positief of negatief was - of voel jy daaroor neutraal? Verduidelik asseblief jou antwoord.

6. Wanneer jy met nuwe inligting werk en jy probeer daaruit sin maak (of probeer om dit vir jouself te verduidelik), in watter taal/tale doen jy dit?

7. Is daar begrippe in jou studieveld wat jy voel dat jy beter verstaan in Engels/Afrikaans? Verduidelik asseblief.

8. Was groter blootstelling aan Engels in lesings of in studiemateriaal beduidend in jou begrip van die werk, of in die leerproses op universiteit? Verduidelik asseblief.

9. Daar is 'n hipotese wat die aaname maak dat tweetaligheid/meertaligheid sekere kognitiewe voordele vir individue inhou.Uit jou eie ondervinding, dink jy dat jou tweetaligheid enige kognitiewe voordele vir jou inhou?

10. Dink jy dat ten opsigte van taal, jou universiteitsopleiding jou voorberei het vir die werkplek?

\section{English}

1. For which modules/subjects did you attend T-option or E-option classes during your first year?

2. In which language(s) do you do your assignments and write tests or exams?

3. Do you think that your English has improved since you have been at university? If yes, what do you attribute the improvement to? If no, would you like to elaborate?

4. Do you think that your first language (Afrikaans) has changed in any way since you have been at university? Please give some explanation.

5. If yes, do you think that this was a positive, negative or neutral change? Please explain your answer. 
6. When you process new information, and you try to make sense of it (or try to explain it to yourself) in which language(s) do you do it?

7. Are there any concepts in your study field which you think you understand better in English/Afrikaans? Please explain your answer.

8. Has greater exposure to English in lectures or in study material been significant in your understanding of work, or in the process of learning at university? Please explain.

9. There is a hypothesis which suggests that bi/multilingualism offers certain cognitive benefits for individuals. From your own experience do you think that bilingualism holds any cognitive benefits for you?

10. Do you think that your university training is preparing you for the working world in terms of language? 